\title{
New drugs in psychiatry: focus on new pharmacological
}

\section{targets [version 1; peer review: 3 approved]}

\section{Filippo Caraci(11,2, Gian Marco Leggio33, Salvatore Salomone³, Filippo Drago(i)3}

\author{
${ }^{1}$ Department of Drug Sciences, University of Catania, Catania, Italy \\ ${ }^{2}$ IRCCS Associazione Oasi Maria S.S., Institute for Research on Mental Retardation and Brain Aging, Troina (EN), Italy \\ ${ }^{3}$ Department of Biomedical and Biotechnological Sciences, University of Catania, Catania, Italy
}

\section{V1 First published: 30 Mar 2017, 6(F1000 Faculty Rev):397 \\ https://doi.org/10.12688/f1000research.10233.1}

Latest published: 30 Mar 2017, 6(F1000 Faculty Rev):397

https://doi.org/10.12688/f1000research.10233.1

\begin{abstract}
The approval of psychotropic drugs with novel mechanisms of action has been rare in recent years. To address this issue, further analysis of the pathophysiology of neuropsychiatric disorders is essential for identifying new pharmacological targets for psychotropic medications. In this report, we detail drug candidates being examined as treatments for psychiatric disorders. Particular emphasis is placed on agents with novel mechanisms of action that are being tested as therapies for depression, schizophrenia, or Alzheimer's disease. All of the compounds considered were recently approved for human use or are in advanced clinical trials. Drugs included here are new antipsychotic medications endowed with a preferential affinity at dopamine D3 receptor (cariprazine) or at glutamatergic or cannabinoid receptors, as well as vortioxetine, a drug approved for managing the cognitive deficits associated with major depression. New mechanistic approaches for the treatment of depression include intravenous ketamine or esketamine or intranasal esketamine. As for Alzheimer's disease, the possible value of passive immunotherapy with agents such as aducanumab is considered to be a potential disease-modifying approach that could slow or halt the progressive decline associated with this devastating disorder.
\end{abstract}

\section{Keywords}

psychotropic drugs, cariprazine, vortioxetine, ketamine oresketamine, aducanumab, neuropsychopharmacology, anti-psychotic

\section{Open Peer Review}

$\begin{array}{rrr}\text { Approval Status } \\ 1 & 2 & 3\end{array}$

version 1

30 Mar 2017

Faculty Reviews are review articles written by the prestigious Members of Faculty Opinions. The articles are commissioned and peer reviewed before publication to ensure that the final, published version is comprehensive and accessible. The reviewers who approved the final version are listed with their names and affiliations.

1. S. J. Enna, Kansas University Medical Center, Kansas City, USA

2. Philippe De Deurwaerdère, Institut des Maladies Neurodégénératives, Bordeaux, France

3. Andrzej Pilc, Polish Academy of Sciences, Krakow, Poland

Michal Korostynski, Polish Academy of Sciences, Krakow, Poland

Any comments on the article can be found at the end of the article. 
Corresponding authors: Filippo Caraci (carafil@hotmail.com), Filippo Drago (fdrago@unict.it)

Competing interests: The author(s) declare that they have no competing interests.

Grant information: The author(s) declared that no grants were involved in supporting this work.

Copyright: $\odot 2017$ Caraci F et al. This is an open access article distributed under the terms of the Creative Commons Attribution License, which permits unrestricted use, distribution, and reproduction in any medium, provided the original work is properly cited.

How to cite this article: Caraci F, Leggio GM, Salomone $S$ and Drago F. New drugs in psychiatry: focus on new pharmacological targets [version 1; peer review: 3 approved] F1000Research 2017, 6(F1000 Faculty Rev):397

https://doi.org/10.12688/f1000research.10233.1

First published: 30 Mar 2017, 6(F1000 Faculty Rev):397 https://doi.org/10.12688/f1000research.10233.1 


\section{Introduction}

Epidemiological data indicate neuropsychiatric disorders as being some of the most prevalent, devastating, and yet poorly treated illnesses. As the approval of central nervous system drugs with novel mechanisms of action has been rare in recent years, there is a critical need to enhance drug discovery in neuropsychopharmacology ${ }^{1}$. To achieve this goal, it is essential to focus on developing drugs that target the pathophysiology underlying the disease, which increases the likelihood of identifying efficacious agents rather than symptomatic treatments. The pathology-to-drug discovery approach specifies that an understanding of the pathophysiology of neuropsychiatric disorders is the required initial step in identifying disease pathways and for validating new pharmacological targets ${ }^{1}$. A more complete understanding of the disease pathways will facilitate both the selection of therapeutic targets and the development of relevant models for screening drug candidates ${ }^{2}$. The pathology-to-drug discovery approach inspired the creation of NEWMEDS (Novel Methods Leading to New Medications in Depression and Schizophrenia), a European project designed to identify specific brain circuits, particularly those involving the prefrontal cortex, that are involved in the pathophysiology and treatment of major depression and schizophrenia $^{3}$. On the other hand, a better knowledge of the mechanism of action of older drugs (the so-called reverse translation approach) has permitted, in part, a better understanding of the pathophysiology of neuropsychiatric diseases, enabling drug design according to the pathology-to-drug discovery approach.

As the neuropsychopharmacology community has only recently adopted the pathology-to-drug discovery approach, it remains unknown whether agents discovered in this way are currently available for the clinical management of psychiatric disorders and whether such drugs display significant advantages over conventional therapies with respect to efficacy and tolerability.

Summarized below are some of the more exciting and relevant advances in the field of neuropsychopharmacology as they pertain to the design and development of novel psychotherapeutics. Highlighted are molecules displaying novel mechanisms of action that were recently approved for human use or that are now undergoing phase II/III clinical trials. Particular emphasis is placed on the identification of new drugs and drug candidates for the treatment of schizophrenia and major depression. Finally, a specific section is dedicated to neurodegenerative disorders such as Alzheimer's disease $(\mathrm{AD})$, where pharmacological strategies can significantly differ from the approaches currently adopted in psychotic and affective disorders.

\section{Schizophrenia}

At a mechanistic level, drug treatments for schizophrenia are presently based on the dopamine hypothesis concerning the symptoms of this disorder ${ }^{4}$. The development of second-generation antipsychotics that began 25 years ago has yielded some advances in terms of efficacy, with some modest improvement in addressing the negative symptoms of this condition, and in tolerability, particularly with regard to extrapyramidal side effects ${ }^{5}$. However, no antipsychotics display robust effects on the cognitive deficits or impaired social processing that are important components of this disorder ${ }^{4}$. For years, the limited efficacy of conventional and second-generation agents has led to theories about whether the manipulation of brain targets other than, or in addition to, the dopamine D2 receptor (D2R) may be necessary for treating this disorder and to significantly improve safety and tolerability.

In recent years, the N-methyl-D-aspartate (NMDA) receptor hypothesis of schizophrenia has been validated in preclinical animal models and humans ${ }^{6}$. According to this theory, the excessive dopamine release in the mesolimbic pathway and the decrease in dopamine release from the mesocortical pathway in the prefrontal cortex, which are responsible for some of the symptoms of schizophrenia, are secondary to a decrease in NMDA receptor control of inhibitory GABAergic neurons. No drugs capable of selectively enhancing NMDA receptor activity in this key brain region have yet been approved for human use. Studies indicate that prodromal and early-in-disease schizophrenic patients have elevated brain glutamate levels compared to healthy controls and ultra-high-risk patients who do not become psychotic ${ }^{7}$. Alterations in NMDA receptor-mediated excitation of GABAergic neurons indicate that schizophrenia is associated with dysfunctional glutamatergic systems in the prefrontal cortex and limbic regions of the brain. One approach has been to target the glutamatergic system using pomaglumetad methionil, a potent and highly selective orthosteric metabotropic glutamate receptor (mGluR) 2/3 agonist ${ }^{8}$, but alternative approaches directed at group III mGluRs are also currently studied in preclinical models of schizophrenia ${ }^{9}$. Preclinical research suggests that by reducing glutamate release, pomaglumetad methionil normalizes heightened glutamate activity in cortical pyramidal neurons ${ }^{8}$. While pomaglumetad methionil was reported to display beneficial effects on both the positive and the negative symptoms of schizophrenia in initial clinical trials, positive results were not obtained in phase III studies. Analysis of the clinical data suggests that pomaglumetad methionil is most efficacious in early-in-disease schizophrenics ( $<3$ years' duration) with a known hyperactive glutamatergic pathophysiology ${ }^{8}$. It is anticipated, therefore, that new antipsychotics acting on the mGluR2/3 will be developed to treat schizophrenic patients in an early phase of the illness with the hope of slowing disease progression and improving prognosis.

The dopamine D3 receptor (D3R) is another pharmacological target that appears to play a prominent role in the pathogenesis of schizophrenia. Unlike the D2R, which has been extensively studied with respect to the symptoms of schizophrenia, little is known about the extent to which changes in D3R and dopamine D4 receptor (D4R) activity contribute to the symptoms of this disorder. It is known that the molecular structure of D3R is very similar to that of D2R and D4R and that in a variety of animal species D2R and D3R share high homology ${ }^{10}$ and identity in the transmembrane regions, including the binding site ${ }^{11}$. Such structural similarities make it difficult to design ligands that selectively interact with D3R. This, in turn, has compromised the ability to fully define the localization and functions of this site. A number of approved drugs that were believed to act primarily at the $\mathrm{D} 2 \mathrm{R}$ recognition site have now 
been found to interact with the D3R as well (see 12 for review). Cariprazine is the first example of a D3R partial agonist that occupies this receptor at doses that produce antipsychotic-like effects in preclinical animal models ${ }^{13,14}$. Cariprazine displays higher affinity at D3R and a similar affinity at D2 and serotonin $2 \mathrm{~B}\left(5-\mathrm{HT}_{2 \mathrm{~B}}\right)$ receptors $^{13}$. In rodents, cariprazine reverses the deficit in novel object recognition that is caused by neonatal administration of phencyclidine ${ }^{14}$ or by subchronic phencyclidine exposure in adults $^{15,16}$. Preclinical and clinical data suggest that by selectively activating D3R, cariprazine may have a positive impact on the cognitive symptoms of schizophrenia. Cariprazine was approved in 2015 by the U.S. Food and Drug Administration for the treatment of schizophrenia ${ }^{17}$. Further clinical studies with cariprazine and other antipsychotics selectively targeting D3R will be essential to validate the role of $\mathrm{D} 3 \mathrm{R}$ as a new pharmacological target for the treatment of cognitive symptoms in schizophrenia.

Another new approach proposed for the treatment of schizophrenia is the development of disease-modifying agents to prevent the full onset of schizophrenia and/or to slow its progression ${ }^{4}$. Many questions remain as to whether it will be possible to identify drugs that will directly affect the underlying disease process in a way that would delay or prevent disease progression in schizophrenia.

There are also many challenges to consider for designing clinical trials to prove that a given drug candidate can modify the course of this disorder over time. A first step might be to identify young individuals who are at high risk for psychosis. Particular emphasis could be placed on those who are also heavy users of cannabis, as there is an increased risk for schizophrenia in those who abuse highly potent preparations of cannabis (so-called "skunk" variants) containing a high percentage of delta-9-tetrahydrocannabinol (THC) (about $15 \%$ ) with a scarcity of cannabidiol (CBD $0-1 \%)^{4,18}$. As a negative allosteric modulator of the cannabinoid 1 (CB1) receptor, CBD ameliorates the psychotogenic effect of THC and may possess antipsychotic properties ${ }^{19}$. Given these findings, the $\mathrm{CB} 1$ receptor has been proposed as a new pharmacological target for the treatment of schizophrenia ${ }^{6,19}$. Indeed, there have been reports that 800 to $1,000 \mathrm{mg}$ of cannabidiol per day safely reduces the signs and symptoms of schizophrenia ${ }^{19}$. However, uncertainty remains about the mechanism of CBD action. Recently, Seeman reported that $\mathrm{CBD}$, like aripiprazole, is a partial agonist at the $\mathrm{D} 2 \mathrm{R}^{20}$. Thus, CBD could be the first molecule of a class of antipsychotics that interact with both the CB1 and the D2R. Ideal candidates for clinical trials with such agents would be high-risk individuals to assess whether CBD dampens the acute psychotic symptoms and cognitive deficits associated with schizophrenia. Three different phase II clinical trials are underway to assess the clinical efficacy of cannabidiol monotherapy in newly diagnosed schizophrenic patients and as adjunctive therapy with conventional second-generation antipsychotics (NCT02088060 and NCT02504151).

\section{Depression}

While currently available antidepressants, such as selective serotonin reuptake inhibitors (SSRIs) and serotonin and noradrenaline reuptake inhibitors (SNRIs), are effective for most patients, approximately $30 \%$ of those with major depressive disorder (MDD) fail to respond to these agents ${ }^{2}$. Cognitive dysfunction represents a distinct biological and clinical dimension in $\mathrm{MDD}^{21}$, with evidence suggesting that the presence of cognitive symptoms in depressed patients can predict a low rate of response to antidepressants and reduced remission rates ${ }^{22,23}$. Multimodal drugs, such as vortioxetine, represent a new class of antidepressants. These agents display multiple molecular mechanisms of action in addition to inhibition of the serotonin transporter ${ }^{24,25}$.

Vortioxetine is a multimodal antidepressant that is thought to act by inhibition of transmitter reuptake and interactions with various 5-HT receptor sites. This pharmacodynamic profile is well described in the Neuroscience-Based Nomenclature, a new pharmacologically driven classification of psychotropic drugs that reflects current knowledge about the underlying neurobiological characteristics of the disorder, an understanding of the neurotransmitter/molecule/system being modified ("pharmacological domain"), and the mode/mechanism of drug action ${ }^{26}$. Vortioxetine is not the only example of a multimodal antidepressant, with others, such as vilazodone (a serotonin transport inhibitor and a $5-\mathrm{HT}_{1 \mathrm{~A}}$ receptor partial agonist), having been approved for the treatment of major depression ${ }^{27,28}$. Other psychotropic drugs developed in the last 30 years can possess a multimodal pharmacodynamic profile (see e.g. trazodone), but the novelty of this approach is to combine multiple pharmacological actions affecting both monoamine targets and other non-monoaminergic systems (e.g. glutamatergic system) $)^{24}$. The multimodal approach seems to be an interesting approach to target the different biological and clinical dimensions of MDD. Current evidence does not suggest a global greater efficacy of multimodal antidepressants compared to SSRIs or SNRIs but an improved efficacy on specific clinical domains where SSRIs or SNRIs are less effective, as observed with vortioxetine, which displays a specific clinical efficacy in the treatment of cognitive deficits associated with $\mathrm{MDD}^{25}$.

Vortioxetine is a $5-\mathrm{HT}_{3}, 5-\mathrm{HT}_{7}$, and $5-\mathrm{HT}_{1 \mathrm{D}}$ receptor antagonist, $5-\mathrm{HT}_{1 \mathrm{~B}}$ receptor partial agonist, 5- $\mathrm{HT}_{1 \mathrm{~A}}$ receptor agonist, and an inhibitor of the serotonin transporter ${ }^{29}$. It is thought to activate the glutamatergic system in rat frontal cortex by blockade of 5- $\mathrm{HT}_{3}$ and $5-\mathrm{HT}_{7}$ receptors. It is reported that, as compared to fluoxetine, vortioxetine displays a superior efficacy in aged mice as a treatment for visuospatial memory and depression-like behavior ${ }^{30}$. The pharmacodynamic profile is consistent with the results of clinical studies indicating that vortioxetine has antidepressant properties as well as positive effects on cognitive function (e.g. memory and executive functioning $)^{25}$. The most common side effects associated 
with this drug are nausea, vomiting, and constipation. Vortioxetine is currently studied as a potential therapeutic alternative for patients who fail to respond to SSRIs or SNRIs ${ }^{31}$.

Drugs, such as ketamine, that are known to affect descending glutamatergic systems represent a new approach for managing treatment-resistant depression (TRD) ${ }^{32}$. Several well-controlled clinical studies indicate that a single ketamine infusion $(0.5 \mathrm{mg} / \mathrm{kg})$ induces a rapid, generally transient, antidepressant effect in addition to small, but significant, increases in psychotomimetic and dissociative symptoms ${ }^{33}$. The ketamine-induced antidepressant effect occurs within 1 to 2 hours following its intravenous administration and may be sustained for up to 2 weeks ${ }^{34}$. This rapid onset of action has stimulated studies to explore the possibility that ketamine may represent a life-saving drug for TRD patients at imminent risk of suicide $^{35}$. Twice- and thrice-weekly administration of ketamine at $0.5 \mathrm{mg} / \mathrm{kg}$ maintains antidepressant efficacy for over 2 weeks with no signs of tolerance ${ }^{36}$.

It is believed that by blocking NMDA receptors on GABAergic interneurons, ketamine causes a rapid, but transient, increase in extracellular glutamate in the prefrontal cortex. At the molecular level, the ketamine-induced blockade of NMDA receptors results in inhibition of elongation factor $2(\mathrm{eF} 2)$ kinase, dephosphorylation of $\mathrm{eF} 2$, and a consequent augmentation of brain-derived neurotrophic factor (BDNF) synthesis ${ }^{32}$. Preclinical and clinical studies with ketamine have resulted in the identification of new pharmacological targets related to NMDA receptor activation or inhibition, such as the NR2B receptor subunit, and the mammalian target of rapamycin (mTOR), a signaling system that controls synaptic plasticity and appears to be a key element in the antidepressant response to ketamine ${ }^{32}$. Recent studies also suggest that the pharmacological profile of ketamine is more complex than being a simple NMDA receptor antagonist because this drug also shows a significant affinity for D2R and opioid receptors as well as for monoamine transporters ${ }^{37}$. Further studies are needed to identify all the molecular mechanisms underlying the rapid-acting antidepressant effects of ketamine. Efforts are now directed towards the development of new antidepressants displaying the efficacy and rapid onset of action of ketamine but lacking its psychotomimetic effects ${ }^{34}$.

Attempts are also underway to exploit the established clinical value of ketamine and its derivatives, such as $S(+)$ ketamine (esketamine), while reducing their side effect potential by administering them intramuscularly or intranasally at doses (e.g. $0.2 \mathrm{mg} / \mathrm{kg}$ ) lower than those used for the intravenous studies ${ }^{38}$. Phase III clinical trials are ongoing to assess the safety and clinical efficacy of intranasal esketamine in patients with TRD (NCT02782104, NCT02133001, and NCT02497287).

An alternative approach to target the glutamatergic system in MDD and mimic ketamine's effects might be the use of mGluR5selective antagonists or negative allosteric modulators ${ }^{39}$. This novel approach stems from the evidence that mGluR5s are functionally involved in the mild modulation of NMDA receptor activity and mGluR5 antagonists exert significant antidepressant effects in animal models of depression by acting as mild NMDA receptor negative modulators ${ }^{39}$. Therefore, mGluR5s have been recently considered as a new target of novel antidepressants, and basimglurant, a negative allosteric modulator of mGluR5, is now in clinical development for the treatment of MDD (NCT00809562 and NCT01437657).

\section{Alzheimer's disease}

$\mathrm{AD}$ is a neurodegenerative disorder characterized by memory loss, cognitive decline, and neuropsychiatric symptoms that interfere with normal daily activities ${ }^{40}$. This disorder is associated with the presence of senile plaques containing amyloid $\beta(A \beta)$, intracellular aggregates of tau protein in neurofibrillary tangles, and progressive neuronal loss. The amyloid cascade hypothesis ${ }^{41}$ posits that overproduction of $A \beta$, or failure to clear this peptide, causes $\mathrm{AD}$ because of the aggregation of monomeric $\mathrm{A} \beta$ species into higher-molecular-weight $\mathrm{A} \beta$ oligomers that results in neuronal cell loss ${ }^{42}$

Current drug therapies for AD treat only the symptoms, such as memory loss, while having no effect on the progression of the disease. Drugs included in this group are cholinesterase inhibitors (donepezil, rivastigmine, and galantamine), which are approved for treating mild to moderate $\mathrm{AD}$, and memantine, an NMDA receptor antagonist, which is used to treat patients with moderate to severe AD.

Much effort has been expended in developing disease-modifying drugs for the treatment of this condition. Such agents would be able to slow the progression of the pathological changes and their effects would persist even after terminating treatment ${ }^{42}$. To date, this effort has failed to yield any clinically effective drugs. One of the difficulties in testing such compounds has been the lack of reliable biomarkers identifying patients in the early stage of the disease. For this reason, most clinical trials were conducted in patients in advanced stages of the disease after irreversible damage to the brain had already occurred. However, the criteria for the diagnosis of $\mathrm{AD}$, revised in 2011 by the National Institute on Aging and the Alzheimer's Association workgroup ${ }^{43}$, now include biomarkers for identifying AD patients earlier. Such individuals are much better candidates for treatment with disease-modifying drugs ${ }^{44}$. The development of these biomarkers increases the likelihood of identifying that cohort of patients that is most likely to respond to disease-modifying drugs.

Immunotherapy directed towards $A \beta$ has been considered a promising approach because it would, in theory, decrease the aggregation and brain deposition of $\mathrm{A} \beta$. Tau immunotherapy has also been explored as a possible means for inhibiting disease progression in $\mathrm{AD}^{45}$. Given problems with vaccines, $\mathrm{A} \beta$ passive immunotherapy is currently the most popular approach for developing disease-modifying drugs for the treatment of $\mathrm{AD}^{42,46}$.

As antibody-based immunotherapy against $\mathrm{A} \beta$ has so far failed to yield positive clinical results, questions are being raised about the validity of the amyloid hypothesis of AD. However, it remains unknown whether the clinical failures reported for bapineuzumab, 
gantenerumab, and solanezumab are due to their inability to reduce the formation of $A \beta$ oligomers or because they were tested in inappropriate populations of $\mathrm{AD}$ patients ${ }^{47,48}$. Unfortunately, encouraging preliminary results obtained with solanezumab have not been confirmed in recent phase III clinical trials ${ }^{47,48}$. This drug is, however, still in clinical development in prodromal AD patients (NCT02008357 and NCT02760602).

The recent positive results with aducanumab in prodromal and mild $\mathrm{AD}$ in a phase Ib trial ${ }^{49,50}$ suggest that the amyloid hypothesis is still consistent with the development of new disease-modifying drugs, based on this hypothesis, in the near future. Aducanumab is the first example of an antibody developed by selecting human B-cell clones triggered by neo-epitopes present in soluble oligomers and insoluble fibrils. That is, only the pathogenic forms of $A \beta^{49}$ are affected without interfering with $A \beta$ monomers that exert a critical role in maintaining neuronal survival, learning, and memory ${ }^{50,51}$. It has been established that aducanumab enters the brain and that 1 year of monthly intravenous infusion reduces brain $\mathrm{A} \beta$ in a dose- and time-dependent manner in patients with prodromal or mild $\mathrm{AD}$. The greatest effects are observed at doses of 3 and $10 \mathrm{mg} / \mathrm{kg}$. This effect was accompanied by a slowing of the clinical decline as measured by the Clinical Dementia Rating - Sum of Boxes and Mini Mental State Examination scores. As already observed with solanezumab, amyloid-related imaging abnormalities (ARIA), such as vasogenic edema, indicate a dose-dependent response in $\mathrm{AD}$ patients ${ }^{49}$. The clinical efficacy of aducanumab must be confirmed in the long-term extension phase of this study as well as in the ongoing phase III clinical trials, which may finally validate the amyloid hypothesis in the field of AD.

\section{Conclusion}

As indicated in this report, the pathology-to-drug discovery approach is now being applied for the identification of new drugs for the treatment of psychiatric disorders (Table 1). This has been responsible, in part, for the identification of new psychiatric medications with novel mechanisms of action (D3R antagonists, vortioxetine, and esketamine). Secondary prevention strategies with glutamatergic agents (mGluR2/3 agonists) or negative allosteric modulators of CB1 (cannabidiol) are under study for the treatment of schizophrenia. If confirmed in ongoing clinical trials, the early results with aducanumab, a possible disease-modifying

Table 1. Current status of clinical development of new psychotropic drugs for the treatment of neuropsychiatric disorders.

\begin{tabular}{|c|c|c|c|c|}
\hline Drug & Indication/field & $\begin{array}{l}\text { Putative } \\
\text { mechanism }\end{array}$ & $\begin{array}{l}\text { Phase of } \\
\text { study of } \\
\text { action }\end{array}$ & $\begin{array}{l}\text { Main result } \\
\text { and/or status }\end{array}$ \\
\hline Pomaglumetad & Schizophrenia & $\begin{array}{l}\text { Agonist on } \\
\text { mGlu2/3 }\end{array}$ & III & $\begin{array}{l}\text { Efficacy only in } \\
\text { schizophrenic } \\
\text { patients with } \\
\text { a duration of } \\
\text { illness }<3 \text { years }\end{array}$ \\
\hline Cariprazine & Schizophrenia & $\begin{array}{l}\text { D3/D2/5-HT2B } \\
\text { ligand with a } \\
\text { preferential affinity } \\
\text { for D3R }\end{array}$ & Approved & Approved \\
\hline Cannabidiol & Schizophrenia & $\begin{array}{l}\text { CB1 negative } \\
\text { allosteric } \\
\text { modulator } \\
\text { D2R partial agonist }\end{array}$ & $\|$ & Ongoing \\
\hline Vortioxetine & Depression & $\begin{array}{l}\text { Multimodal } \\
\text { (5-HT receptor } \\
\text { agonist/antagonist } \\
\text { reuptake inhibitor) }\end{array}$ & Approved & Approved \\
\hline Vilazodone & Depression & Multimodal & Approved & Approved \\
\hline $\begin{array}{l}\text { Ketamine } \\
\text { (esketamine) }\end{array}$ & Depression & NMDA antagonist & III & Ongoing \\
\hline Aducanumab & $\begin{array}{l}\text { Alzheimer's } \\
\text { disease }\end{array}$ & A $\beta$ clearance & III & Ongoing \\
\hline
\end{tabular}

5-HT, serotonin; A 3 , amyloid beta; CB1, cannabinoid 1; D2R, dopamine 2 receptor; D3R, dopamine 3 receptor; mGlu, metabotropic glutamate; NMDA, N-methyl-D-aspartate 
agent for $\mathrm{AD}$, suggest that the pathology-to-drug discovery approach may be applicable for designing and developing new medications for the treatment of a host of neuropsychiatric disorders.

\section{Abbreviations}

5-HT, serotonin; A $\beta$, amyloid beta; AD, Alzheimer's disease; CBD, cannabidiol; CB1 receptor, cannabinoid 1 receptor; D2R, dopamine 2 receptor; D3R, dopamine 3 receptor; D4R, dopamine $\mathrm{D} 4$ receptor; eF2, elongation factor; MDD, major depressive disorder; mGluR, metabotropic glutamate receptor; mTOR, mammalian target of rapamycin; NMDA, N-methyl-D-aspartate; SNRI, serotonin and noradrenaline reuptake inhibitor; SSRI, selective serotonin reuptake inhibitor; THC, delta-9-tetrahydrocannabinol; TRD, treatment-resistant depression.

\section{Competing interests}

The author(s) declare that they have no competing interests.

\section{Grant information}

The author(s) declared that no grants were involved in supporting this work.
1. F Millan MJ, Goodwin GM, Meyer-Lindenberg A, et al:: Learning from the past and looking to the future: Emerging perspectives for improving the treatment of psychiatric disorders. Eur Neuropsychopharmacol. 2015; 25(5): 599-656. PubMed Abstract | Publisher Full Text | F1000 Recommendation

2. Pangalos MN, Schechter LE, Hurko O: Drug development for CNS disorders: strategies for balancing risk and reducing attrition. Nat Rev Drug Discov. 2007; 6(7): 521-32.

PubMed Abstract | Publisher Full Text

3. Artigas F, Schenker E, Celada $P$, et al.: Defining the brain circuits involved in psychiatric disorders: IMI-NEWMEDS. Nat Rev Drug Discov. 2016; 16(1): 1-2. PubMed Abstract | Publisher Full Text

4. Millan MJ, Andrieux A, Bartzokis G, et al.: Altering the course of schizophrenia: progress and perspectives. Nat Rev Drug Discov. 2016; 15(7): 485-515. PubMed Abstract | Publisher Full Text

5. F Garay RP, Citrome L, Samalin L, et al.: Therapeutic improvements expected in the near future for schizophrenia and schizoaffective disorder: an appraisal of phase III clinical trials of schizophrenia-targeted therapies as found in US and EU clinical trial registries. Expert Opin Pharmacother. 2016; 17(7): 921-36. PubMed Abstract | Publisher Full Text | F1000 Recommendation

6. $\mathrm{F}$ Howes $\mathrm{O}$, McCutcheon $\mathrm{R}$, Stone $\mathrm{J}$ : Glutamate and dopamine in schizophrenia: an update for the $21^{\text {st }}$ century. J Psychopharmacol. 2015; 29(2): 97-115.

PubMed Abstract | Publisher Full Text | Free Full Text | F1000 Recommendation

7. de la Fuente-Sandoval C, Léon-Ortiz P, Favila R, et al:: Higher levels of glutamate in the associative-striatum of subjects with prodromal symptoms of schizophrenia and patients with first-episode psychosis. Neuropsychopharmacology. 2011; 36(9): 1781-1791. PubMed Abstract | Publisher Full Text | Free Full Text

8. $\quad \mathrm{F}$ Kinon BJ, Millen BA, Zhang L, et al.: Exploratory analysis for a targeted patient population responsive to the metabotropic glutamate $2 / 3$ recepto agonist pomaglumetad methionil in schizophrenia. Biol Psychiatry. 2015; 78(11): $754-62$.

PubMed Abstract | Publisher Full Text | F1000 Recommendation

9. Wierońska JM, Acher FC, Sławińska A, et al:: The antipsychotic-like effects of the mGlu group III orthosteric agonist, LSP1-2111, involves 5-HT signalling. Psychopharmacology (Berl). 2013; 227(4): 711-25. PubMed Abstract | Publisher Full Text | Free Full Text

10. Sibley DR, Monsma FJ Jr: Molecular biology of dopamine receptors. Trends Pharmacol Sci. 1992; 13(2): 61-69. PubMed Abstract | Publisher Full Tex

11. Shi $L$, Javitch JA: The binding site of aminergic $G$ protein-coupled receptors the transmembrane segments and second extracellular loop. Annu Rev Pharmacol Toxicol. 2002; 42: 437-467. PubMed Abstract | Publisher Full Text

12. Leggio GM, Bucolo $\mathrm{C}$, Platania $\mathrm{CB}$, et al:: Current drug treatments targeting dopamine D3 receptor. Pharmacol Ther. 2016; 165: 164-77. PubMed Abstract | Publisher Full Text

13. F De Deurwaerdère P: Cariprazine:New dopamine biased agonist for neuropsychiatric disorders. Drugs Today (Barc). 2016; 52(2): 97-110. PubMed Abstract | Publisher Full Text | F1000 Recommendation

14. F Watson DJ, King MV, Gyertyán I, et al:: The dopamine $\mathbf{D}_{3}$-preferring $D_{2} / D_{3}$ dopamine receptor partial agonist, cariprazine, reverses behavioural changes in a rat neurodevelopmental model for schizophrenia. Eur Neuropsychopharmacol. 2016; 26(2): 208-224.

PubMed Abstract | Publisher Full Text | F1000 Recommendation

15. Nagai T, Murai R, Matsui K, et al:: Aripiprazole ameliorates phencyclidineinduced impairment of recognition memory through dopamine $D_{1}$ and serotonin 5- $\mathrm{HT}_{1 \mathrm{~A}}$ receptors. Psychopharmacology (Berl). 2009; 202(1-3): 315-328.

PubMed Abstract | Publisher Full Text

16. F Neill JC, Grayson B, Kiss B, et al:: Effects of cariprazine, a novel antipsychotic on cognitive deficit and negative symptoms in a rodent model of schizophrenia symptomatology. Eur Neuropsychopharmacol. 2016; 26(1): 3-14. PubMed Abstract | Publisher Full Text | F1000 Recommendation

17. Citrome L: Cariprazine for the Treatment of Schizophrenia: A Review of this Dopamine D3-Preferring D3/D2 Receptor Partial Agonist. Clin Schizophr Relat Psychoses. 2016; 10(2): 109-19.

PubMed Abstract | Publisher Full Text

18. F Di Forti M, Marconi A, Carra E, et al.: Proportion of patients in south London with first-episode psychosis attributable to use of high potency cannabis: a case-control study, Lancet Psychiatry. 2015; 2(3): 233-8. PubMed Abstract | Publisher Full Text | F1000 Recommendation

19. $\mathrm{F}$ Leweke FM, Mueller JK, Lange B, et al.: Therapeutic Potential of Cannabinoids in Psychosis. Biol Psychiatry. 2016; 79(7): 604-12. PubMed Abstract | Publisher Full Text | F1000 Recommendation

20. F Seeman P: Cannabidiol is a partial agonist at dopamine D2High receptors, predicting its antipsychotic clinical dose. Transl Psychiatry. 2016; 6(10): e920. PubMed Abstract | Publisher Full Text | Free Full Text | F1000 Recommendation

21. Mclntyre RS, Cha DS, Soczynska JK, et al:: Cognitive deficits and functional outcomes in major depressive disorder: determinants, substrates, and treatment interventions. Depress Anxiety. 2013; 30(6): 515-27. PubMed Abstract | Publisher Full Text

22. Castellano S, Ventimiglia A, Salomone S, et al:: Selective Serotonin Reuptake Inhibitors and Serotonin and Noradrenaline Reuptake Inhibitors Improve Cognitive Function in Partial Responders Depressed Patients: Results from a Prospective Observational Cohort Study. CNS Neurol Disord Drug Targets. 2016; 15(10): 1290-1298.

PubMed Abstract | Publisher Full Text

23. F Roca M, Monzón S, Vives $\mathrm{M}$, et al:: Cognitive function after clinical remission in patients with melancholic and non-melancholic depression: a 6 month follow-up study. J Affect Disor. 2015; 171: 85-92. PubMed Abstract | Publisher Full Text | F1000 Recommendation

24. Richelson E: Multi-modality: a new approach for the treatment of major depressive disorder. Int J Neuropsychopharmacol. 2013; 16(6): 1433-1442. PubMed Abstract | Publisher Full Text | Free Full Text

25. F Thase ME, Mahableshwarkar AR, Dragheim M, et al:: A meta-analysis of randomized, placebo-controlled trials of vortioxetine for the treatment of major depressive disorder in adults. Eur Neuropsychopharmacol. 2016; 26(6): 979-93. PubMed Abstract | Publisher Full Text | F1000 Recommendation

26. F Zohar J, Stahl S, Moller HJ, et al.: A review of the current nomenclature for psychotropic agents and an introduction to the Neuroscience-based Nomenclature. Eur Neuropsychopharmacol. 2015; 25(12): 2318-2325. PubMed Abstract | Publisher Full Text | F1000 Recommendation

27. Wang SM, Han C, Lee SJ, et al.: Vilazodone for the treatment of major 
depressive disorder: focusing on its clinical studies and mechanism of action. Psychiatry Investig. 2015; 12(2): 155-63.

PubMed Abstract | Publisher Full Text | Free Full Text

28. Al-Sukhni M, Maruschak NA, McIntyre RS: Vortioxetine : a review of efficacy, safety and tolerability with a focus on cognitive symptoms in major depressive disorder. Expert Opin Drug Saf. 2015; 14(8): 1291-304. PubMed Abstract | Publisher Full Text

29. F Sanchez C, Asin KE, Artigas F: Vortioxetine, a novel antidepressant with multimodal activity: Review of preclinical and clinical data. Pharmacol Ther. 2015; 145: 43-57.

PubMed Abstract | Publisher Full Text | F1000 Recommendation

30. F Li Y, Abdourahman A, Tamm JA, et al:: Reversal of age-associated cognitive deficits is accompanied by increased plasticity-related gene expression after chronic antidepressant administration in middle-aged mice. Pharmacol Biochem Behav. 2015; 135: 70-82.

PubMed Abstract | Publisher Full Text | F1000 Recommendation

31. F Brignone M, Diamand F, Painchault C, et al.: Efficacy and tolerability of switching therapy to vortioxetine versus other antidepressants in patients with major depressive disorder. Curr Med Res Opin. 2016; 32(2): 351-66. PubMed Abstract | Publisher Full Text | F1000 Recommendation

32. Duman RS: Neurobiological advances identify novel antidepressant targets. World Psychiatry. 2013; 12(3): 207-9.

PubMed Abstract | Publisher Full Text | Free Full Text

33. Rasmussen KG: Has psychiatry tamed the "ketamine tiger?" Considerations on its use for depression and anxiety. Prog Neuropsychopharmacol Biol Psychiatry. 2016; 64: 218-24.

PubMed Abstract | Publisher Full Text

34. Sanacora G, Schatzberg AF: Ketamine: promising path or false prophecy in the development of novel therapeutics for mood disorders? Neuropsychopharmacology. 2015; 40(2): 259-67. PubMed Abstract | Publisher Full Text | Free Full Text

35. Bobo WV, Voort JL, Croarkin PE, et al.: Ketamine For Treatment-Resistant Unipolar And Bipolar Major Depression: Critical Review And Implications For Clinical Practice. Depress Anxiety. 2016; 33(8): 698-710. PubMed Abstract | Publisher Full Text

36. F Singh JB, Fedgchin M, Daly EJ, et al: A Double-Blind, Randomized, PlaceboControlled, Dose-Frequency Study of Intravenous Ketamine in Patients With Treatment-Resistant Depression. Am J Psychiatry. 2016; 173(8): 816-26. PubMed Abstract | Publisher Full Text | F1000 Recommendation

37. F Ficek J, Zygmunt M, Piechota M, et al:: Molecular profile of dissociative drug ketamine in relation to its rapid antidepressant action. BMC Genomics. 2016; 17: 362 .

PubMed Abstract | Publisher Full Text | Free Full Text | F1000 Recommendation

38. F Lapidus KA, Levitch CF, Perez AM, et al:: A randomized controlled trial of intranasal ketamine in major depressive disorder. Biol Psychiatry. 2014; 76(12) 970-6.

PubMed Abstract | Publisher Full Text | Free Full Text | F1000 Recommendation
39. F Pałucha-Poniewiera A, Pilc A: Glutamate-Based Drug Discovery for Novel Antidepressants. Expert Opin Drug Discov. 2016; 11(9): 873-83. PubMed Abstract | Publisher Full Text | F1000 Recommendation

40. Ballard CG, Gauthier S, Cummings JL, et al:: Management of agitation and aggression associated with Alzheimer disease. Nat Rev Neurol. 2009; 5(5): 245-55.

PubMed Abstract | Publisher Full Text

41. Selkoe DJ, Hardy J: The amyloid hypothesis of Alzheimer's disease at 25 years. EMBO Mol Med. 2016; 8(6): 595-608.

PubMed Abstract | Publisher Full Text | Free Full Text

42. Salomone S, Caraci F, Leggio GM, et al: New pharmacological strategies for treatment of Alzheimer's disease: focus on disease modifying drugs. Br J ClinPharmacol. 2012; 73(4): 504-17.

PubMed Abstract | Publisher Full Text | Free Full Text

43. Albert MS, DeKosky ST, Dickson D, et al.: The diagnosis of mild cognitive impairment due to Alzheimer's disease: recommendations from the National Institute on Aging-Alzheimer's Association workgroups on diagnostic guidelines for Alzheimer's disease. Alzheimers Dement. 2011; 7(3): 270-9.

PubMed Abstract | Publisher Full Text | Free Full Text

44. Caraci F, Castellano S, Salomone S, et al:: Searching for disease-modifying drugs in AD: can we combine neuropsychological tools with biological markers? CNS Neurol Disord Drug Targets. 2014; 13(1): 173-86. PubMed Abstract | Publisher Full Text

45. F Sigurdsson EM: Tau Immunotherapy. Neurodegener Dis. 2016; 16(1-2): $34-8$.

PubMed Abstract | Publisher Full Text | Free Full Text | F1000 Recommendation

46. F Wisniewski T, Goñi F: Immunotherapeutic approaches for Alzheimer's disease. Neuron. 2015; 85(6): 1162-76. PubMed Abstract | Publisher Full Text | Free Full Text | F1000 Recommendation

47. Shifu X: F1000Prime Recommendation of [Doody RS et al., N Engl J Med 2014 370(4): 311-21]. In F1000Prime. 2014.

Publisher Full Text

48. Siemers ER, Sundell KL, Carlson C, et al:: Phase $\mathbf{3}$ solanezumab trials: Secondary outcomes in mild Alzheimer's disease patients. Alzheimers Dement. 2016; 12(2): $110-20$.

PubMed Abstract | Publisher Full Text

49. $F$ Sevigny $\mathrm{J}$, Chiao $P$, Bussière $T$, et al.: The antibody aducanumab reduces $A$ plaques in Alzheimer's disease. Nature. 2016; 537(7618): 50-6 PubMed Abstract | Publisher Full Text | F1000 Recommendation

50. F Giuffrida ML, Caraci F, Pignataro B, et al.: Beta-amyloid monomers are neuroprotective. J Neurosci. 2009; 29(34): 10582-10587. PubMed Abstract | Publisher Full Text | F1000 Recommendation

51. F F1000Prime Recommendations, Dissents and Comments for [SevignyJ et al., Nature 2016, 537: 50-6]. In F1000Prime. 2016.

F1000 Recommendation 


\section{Open Peer Review}

\section{Current Peer Review Status:}

\section{Editorial Note on the Review Process}

Faculty Reviews are review articles written by the prestigious Members of Faculty Opinions. The articles are commissioned and peer reviewed before publication to ensure that the final, published version is comprehensive and accessible. The reviewers who approved the final version are listed with their names and affiliations.

\section{The reviewers who approved this article are:}

\section{Version 1}

\section{Andrzej Pilc}

Department of Neurobiology, Institute of Pharmacology, Polish Academy of Sciences, Krakow, Poland Michal Korostynski

Department of Molecular Neuropharmacology, Institute of Pharmacology, Polish Academy of Sciences, Krakow, Poland

Competing Interests: No competing interests were disclosed.

2. Philippe De Deurwaerdère

CNRS, Institut des Maladies Neurodégénératives, Bordeaux, France

Competing Interests: No competing interests were disclosed.

\section{S. J. Enna}

Research and Graduate Education, Department of Physiology and Pharmacology, Kansas University Medical Center, Kansas City, KS, USA

Competing Interests: No competing interests were disclosed. 
The benefits of publishing with F1000Research:

- Your article is published within days, with no editorial bias

- You can publish traditional articles, null/negative results, case reports, data notes and more

- The peer review process is transparent and collaborative

- Your article is indexed in PubMed after passing peer review

- Dedicated customer support at every stage

For pre-submission enquiries, contact research@f1000.com 